Seloka: Jurnal Pendidikan Bahasa dan Sastra Indonesia
UNNES (2) (2020): $159-167$
https://journal.unnes.ac.id/sju/index.php/seloka

\title{
Determinants of Language Attitudes of Elshinta Semarang Radio News Broadcasters and Radio Republik Indonesia (RRI) Pro 1 Semarang
}

\author{
Moh. Henri Prasetiyo ${ }^{1 \bowtie}$ Fathur Rokhman $^{2}$, Ida Zulaeha ${ }^{2}$ \\ DOI: https://doi.org/10.15294/seloka.v9i2. 40163 \\ ${ }^{1}$ Radio Elshinta Semarang, Indonesia \\ ${ }^{2}$ Universitas Negeri Semarang, Indonesia
}

\begin{tabular}{|c|c|}
\hline Article Info & Abstract \\
\hline $\begin{array}{l}\text { History Articles } \\
\text { Received: } \\
\text { 19 March } 2020 \\
\text { Accepted: } \\
\text { 19 June 2020 } \\
\text { Published: } \\
21 \text { August } 2020 \\
\text { Keywords: } \\
\text { Attitude, news } \\
\text { broadcaster, radio } \\
\text { elshinta semarang, } \\
\text { radio republik } \\
\text { indonesia pro } 1 \\
\text { semarang }\end{array}$ & $\begin{array}{l}\text { The reality in the media world today is that apart from RRI and TVRI, private } \\
\text { radio and television are also very concerning in their role as the coach of the } \\
\text { Indonesian language. The purpose of this study was to analyze the factors that } \\
\text { tend to influence the attitude of the news announcers Radio Elshinta Semarang } \\
\text { and RRI Pro } 1 \text { Semarang. This research design uses descriptive qualitative. The } \\
\text { data collection method used was the observation method. The data collection } \\
\text { technique in this study was a record and note technique. The instrument in this } \\
\text { study was the researcher himself. Data collection tools used were data collection } \\
\text { guides and data cards. Miles and Huberman's data analysis model was used in } \\
\text { this study. Based on the results of data analysis, internal factors that affect the } \\
\text { language attitudes of news announcers Radio Elshinta Semarang and Radio } \\
\text { Republik Indonesia (RRI) pro } 1 \text { Semarang are language mastery factors } \\
\text { (cognitive component), other language mastery factors (language contact), } \\
\text { preference factors (affective component) and language ideology factor (language } \\
\text { belief). The results of this study provide theoretical and practical advantages. } \\
\text { The benefits of this study can produce concepts regarding language attitudes in } \\
\text { order to enhance sociolinguistic scientific treasures and help understanding } \\
\text { sociolinguistic studies, especially in relation to language attitudes and can be a } \\
\text { guide for news broadcasters to be able to be positive in speaking in public spaces. }\end{array}$ \\
\hline
\end{tabular}

Correspondence address:

Jalan Bukit Puncak No 1, Bukitsari Semarang Jawa Tengah

E-mail: henrielshinta@gmail.com 


\section{INTRODUCTION}

Language is a means of communicating with other people to convey information, ideas, feelings, and opinions on something. Widianto and Zulaeha (2016) state that language selection occurs to achieve a speaker's goal. Communication conveying these ideas is also a manifestation of one's self-actualization in the circle of the environment. Apriliyani \& Rokhman (2016) state that in communication, language has various functions, one of which is to create cooperative relationships between people. The language function to express itself is part of the expression function. As a means of selfexpression, language is expressed regardless of who the target is, but only as a personal interest, at least as a form of self-existence (Wahyu, 2006: 6). However, this communication cannot be separated from the social and cultural conditions of the speakers. Language as a socio-cultural product leads us to an understanding of the meaning of language from the perspective of society as language users (Zulaeha, 2016).

The expression of a person's feelings and beliefs on the choice of language is manifested in the form of language attitudes. Secord and Backman (in Azwar 2012: 5) state that attitudes are certain regularities in terms of feelings (affection), thoughts (cognition), and predisposition of one's actions (conation) to an aspect of the surrounding environment. A person's attitude will be actualized through his language behavior. This is also in accordance with the opinion of Garvin and Mathiot (in Suwito, 1996: 31) which explains the main characteristics of a person's language attitude, namely language loyalty, language pride, and awareness of language norms. Adyana (2016) states that speakers must be able to choose the correct language code so that communication can take place smoothly and naturally. Code variations in communication in society cause speakers to produce speech code choices based on the situation that occurs and the speaker's communicative competence (Eliya and Zulaeha, 2017). Therefore, in a person's language, there is also an expression of his feelings for the choice of vocabulary or language used to express something.

Indonesian, which is the identity of the nation, should become the language ideology of the Indonesian people by showing a positive language attitude through everyday language behavior in accordance with the provisions. Wardhani (2018) states that even language can become a reflection of the character of the nation. However, the era of globalization is a challenge for the Indonesian people to maintain their identity in the very complex circle of international interactions. However, Marsudi and Zahrok (2015) state that the loyalty of Indonesian speakers to their language has reached an alarming level. Many Indonesianspeaking people are not aware and even don't know if the language used or written is wrong. Many people think that the deviation in the Indonesian language used is considered the correct language. Koentjaraningrat (1990) shares some of the negative traits of Indonesian society that are reflected when speaking, namely (1) underestimating quality, (2) mentality of breaking through, (3) lack of self-esteem, (4) shunning discipline, (5) reluctance to take responsibility, and ( 6) like to talk about or join in. This is because one of them is the hegemony of foreign languages against languages in Indonesia (Savitri, 2015).

The phenomenon of language deviation has also become commonplace in the mass media. Sumita Tobing (1991) explained the reality in the world of media today, apart from RRI and TVRI, private radio and television are also very concerned about their role as the coach of the Indonesian language. In this case, RRI Pro 1 Semarang, which is the only news radio owned by the government and Radio Elshinta Semarang, which has dedicated itself as a 24-hour news radio, is interesting to research. In the current reality, the problem of language development is not yet the main work that must be the main capital in producing programs in the mass media and is often ignored by media owners (Alwi et al., 2000: 585). However, Anwar (1984: 1) has the view that journalistic language must comply with grammar rules, pay attention to the 
use of spelling, and follow the development of vocabulary in society.

The purpose of this study was to analyze what factors influence the language attitudes of news announcers Radio Elshinta Semarang and RRI Pro 1 Semarang.

The relevant research is the work of Ranasuriya (2015) in his research entitled "Effects of Radio and Television Media on Language". This study concluded that broadcasters used code-switching to be superior to others. They use code-switching as a tool to attract listeners. However, some listeners realize that the use of English in the middle of a Sinhala presentation is dangerous.

\section{METHOD}

The theoretical approach used in this research is the sociolinguistic approach. The use of a sociolinguistic approach in this study is focused on the sociological method. The sociological method is used to collect data based on the context of the conversation that occurs. This research design uses descriptive qualitative. The data used in this research is a piece of speech taken from 6 Elshinta radio news announcers and 6 news announcers RRI Pro 1 Semarang which contain the actualization of the affective and conative components of broadcasters on the use of their language.

The data collection method used was the observation method. The technique of collecting data in this study is a record and note technique. The instrument in this study was the researcher himself. Language attitudes and language attitudes factors become the independent variables in this study, while the news announcers Radio Elshinta Semarang and RRI Pro 1 Semarang are the dependent variables in this study. Data collection tools used data collection guidelines and data cards. Miles and Huberman's data analysis model (in Sugiono, 2008: 237) was used in this study. Activities in data analysis, namely: data reduction, data presentation, and concluding. The data validity test used was the triangulation of data sources. The data on the data card obtained from the analysis of speech when reading the news are compared with the data from the analysis of speech when interviewing the sources.

\section{RESULTS AND DISCUSSION}

The tendency of the language attitude of the news broadcasters Radio Elshinta Semarang and Radio Republik Indonesia (RRI) Pro 1 Semarang is influenced by two factors. These two factors are internal factors and external factors. These two factors are seen as a symptom of the use of foreign languages and inappropriate use of Indonesian language rules among the media. The language attitude tendency factor is described as follows

\section{Internal Factor}

Internal factors relate to the background of the news announcer's decision to compose a sentence, choose words, and use words in the sentence. Internal factors that determine language selection identified in news announcer speech are (1) language mastery factor (cognitive component) news announcer, (2) other language mastery factors (language contact), and (3) preference factors (affective component) and language loyalty. These two factors will be described as follows.

\section{Language Mastery Factor}

Mastery of language is the most basic aspect of a person in communicating. A person will not be able to communicate properly and correctly if he does not master the language to be used. Mastery of language becomes an absolute basic factor when someone will play with language. The use of language as an attitude of pride by developing the language from its original meaning, of course, the announcer must master or know the conceptual meaning of the word to be used first so that it will fit the context of the sentence to be attached. If the announcer does not know the conceptual meaning of the word to be used, the sentence construction that will be arranged is discordant, there will be a word that is appropriate to the context of the sentence being built. This language mastery factor will tend to be 
easier to observe when the announcer speaks alone (without a speech partner) because at that time the announcer stands on his knowledge. This language mastery factor includes mastery of Indonesian language rules that are good and correct, as well as mastery of the vocabulary that is stored in his knowledge. Here's the explanation

\section{Speech Fragments :}

Jokowi berharap inisiatif partai Nasdem yang mendirikan akademi bela negara bisa diikuti partai lain, organisasi lain, institusi lain atau siapa pun yang peduli pada kemajuan bangsa.

The sentence construction compiled by the RRI Pro 1 Semarang announcer is in accordance with the standard Indonesian grammar. The announcer's speech is an equivalent compound sentence using the conjunction 'or'. The construction of compound sentences that are arranged is in accordance with the rules. The function of all phrases is also self-explanatory. The sentence consists of the subject, predicate, and object functions. Subjects and predicates that form the basis of sentence formation are fulfilled in the sentence. The phrases used in the sentence are parallel/parallel. The parallel phrase is "can be followed by other parties, other organizations, other institutions or anyone who cares about the progress of the nation". The phrases used are similar so that they are said to be parallel or parallel, there are no stray phrases. The correct compound sentence construction, the function of each phrase that has been appropriate and the alignment of the phrases in the compiled sentence are in accordance with the rules for effective sentence formation.

\section{Other Language Mastery Factors (Language Contact)}

Mastery of more than one language in an announcer makes it necessary to choose the knowledge he will use, be it vocabulary, structure, or meaning. Mastery of more than one language that goes well if used according to the conditions. If the conditions are normal, the use of good and correct Indonesian is recommended. However, if there is an important purpose or urgency, it is permissible to change the code or mix the code. Mastery of more than one language will be problematic if there is a leaky diglossia or mixed language (mixed language). Here's the explanation.

\section{Speech 1 :}

Wakil Ketua Komisi Pemberantasan Korupsi (KPK), Alexander Marwanta menyatakan KPK mendorong penerapan egovernment untuk meningkatkan kualitas pelayanan publik dan mencegah praktik korupsi.

\section{Speech 2 :}

Tahapan Pemilihan Gubernur (Pilgub) Jateng 2018 akan dimulai sekitar Agustus 2017. Komisi Pemilihan Umum (KPU) Jateng menetapkan Data Pemilih Tetap (DPT) berdasarkan KTP Elektronik (e-KTP). Koordinasi terus dilakukan terutama dengan Dinas Kependudukan dan Pencatatan Sipil (Dispendukcapil) untuk menyiapkan data masyarakat yang sudah melakukan perekaman eKTP.

The two utterances are utterances uttered by the Elshinta Radio announcer. The two sentences contain two acronyms that look the same but are different, namely e-government and e-KTP. The difference between the two can be seen at a glance, namely that e-government uses English vocabulary, while e-KTP is an acronym that uses Indonesian. If you follow the origin of the language, the word e-government is lengthened to electronic government, while the word e-KTP if it is extended becomes an electronic Identity Card. Electronic Identity Card is different from the meaning of the sentence which is written KTP (Kartu Tanda Penduduk) electronically. In terms of meaning, the Electronic Identity Card and Electronic Identity Card (KTP) have the same reference and meaning. However, the two phrases feel odd and different due to the different structure of the sentence construction. Electronic Identity Card is built on the explanation structure is explained (MD), while the electronic Identity Card is built on the structure explained (DM). The explain explained structure (MD) is not known in Indonesian. This structure is characteristic of the 
structure of the English language. The structure of phrases that exist in Indonesian is only explained to explain (DM). On that basis, the word e-KTP which is pronounced by the announcer is built on Indonesian vocabulary and is influenced by his knowledge of English because it uses the English structure, namely explain explained (DM). This violates language rules. Supposedly, phrases in Indonesian must be built using Indonesian vocabulary and structures as well. The pattern of e-KTP word-formation indicates that there are factors of mastery of other languages (language contact). However, language contacts that do not comply with the rules cause these phrases to be mixed up (mix language).

A different symptom is found in the phrase e-government. The phrase e-government does not fall into a language error, in contrast to e-KTP. This is because the words used in e-government (electronic government) are entirely English vocabulary so that the structure used must also be English (explain explained / MD). The phrase egovernment is classified into the category of codeswitching in sociolinguistic studies.

\section{Favorite Factor (Affective Component)}

After it is known that broadcasters can master several languages, the determining factor for the next language choice is the preference factor (affective component). The dimension of language contact that occurs within the announcer requires the announcer to choose which language to use. Broadcasters choose the language used based on the preference for a particular language code so that the preferred language code will be used frequently in their speech. If the announcer likes English, the announcer will more often insert the English lingual unit in the sentence he will compose.

The liking factor (Affective Component) not only affects language contact based on mastery of several languages by the broadcaster but also when language contact occurs based on the presence of the speech partner. Language contact that occurs due to the presence of a speech partner is that the announcer has another choice in communicating, namely standing on his language knowledge or standing on the attitude/knowledge of the language of the speech partner that enters the speaker through the communication process. In this communication process, the affective factor (preference) will affect the choice of words to be used. Here's the explanation.

\section{Speech :}

Riyono yang sekaligus Ketua Himpunan Petani Nelayan Seluruh Indonesia tingkat Provinsi Jawa Tengah menambahkan dengan adanya para entrepreneur baru maka ke depan para pemuda yang berprofesi sebagai petani di provinsi setempat dapat meningkatkan perekonomian masyarakat.

This sentence was uttered by the news announcer RRI Pro 1 Semarang when reading an article about the interest of young farmers to cultivate rice fields. This sentence contains the English vocabulary, namely the entrepreneur. The word 'entrepreneur' already has its Indonesian equivalent, namely entrepreneur. The word 'entrepreneur' is not a new vocabulary in the Big Indonesian Dictionary and is a vocabulary that is often used in everyday life. Likewise, the word "entrepreneur" is also not an unfamiliar English vocabulary and is a vocabulary that is often used, so it is likely that broadcasters already have the equivalent of the word "entrepreneur", namely "entrepreneur" in their minds. When that happens, the broadcaster has two choices that can be taken on the reading, namely to keep using the vocabulary "entrepreneur" according to the reading or replace it on their initiative with the equivalent of the word in Indonesian, namely by using the word "entrepreneur". However, the diction which is chosen in reading the sentence is still "entrepreneur" which is the English vocabulary. For this choice, the actualized effective component in the broadcaster's conative component shows that he prefers the word 'entrepreneur' to use the word 'entrepreneur'. The choice of favorite (affective component) of the announcer also shows a tendency for aspects of language loyalty. 
Factors of Language Ideology (Belief in Language)

Text is not just a series of sentences consisting of subjects, predicates, objects, and other functions; but behind the discourse/text, a certain ideology is "hidden" (Santoso, 2009). Apart from text, the speech also contains a certain ideology. the choice of words is adjusted according to the affective component and the purpose of speaking. The ideology of language is a person's belief that is built on knowledge and love for a language so that he will implement the language in his daily life as a manifestation of his style (style) and character (self-identity) as an individual and as his pride. The ideology of language encompasses language loyalty and pride. The ideology of the language of the Indonesian people was declared on October 28, 1928, during the youth oath, which was strengthened by article 36 of the 1945 Constitution. However, over time, the ideology of Indonesian society's language faded due to pressure from foreign languages so that the language knowledge possessed by individuals Indonesian society is not entirely Indonesian so that its ideology is not Indonesian. The condition of language development that has been very rapid (multilingual society) makes two conditions of the communication process experienced by a person, especially broadcasters, namely (1) monologue when an announcer speaks on his own or delivers the news, he stands in two choices, using the knowledge of Indonesian that he has mastered. or using another language that he is also good at, and (2) dialogue, when the announcer communicates with the speech partner, he will stand on two choices, using knowledge of Indonesian which is believed to be true as a response or following the knowledge of the speech partner which may be different from his knowledge in response. The ideology of language (belief) of a person is the final determinant of one's choice of language attitude from these two conditions.

The ideological factor of language is a determining factor in the choice of broadcast language. When a broadcaster likes a code in another language, but he has a language ideology, the announcer will return to using the same language code in compiling the sentence he will say. Conversely, when a broadcaster likes a code in another language and the broadcaster does not have a language ideology, then the broadcasters will often use the foreign language lingual unit in their speech.

The presence of a speech partner is a test of the broadcaster's ideology. After the announcer has finished with the attitude chosen for several language abilities, then the announcer is tested for language ideology by the inclusion of attitudes/language knowledge from the speech partner into the announcer through the communication process from the speech partner's speech received by the speaker. In essence, someone's speech contains language attitudes and language attitudes contain the ideology of one's language which will be absorbed by the speech partner through the communication process. This language ideology that will test the language fidelity of the speech partners, in this case, is the news announcer.

\section{Contexts :}

The announcer interviewed the Director of the Semarang Bunda and Buah Hati Foundation, Dyah Woro Haswini, about children involved in juvenile delinquency cases such as bullying and violence.

\section{Speech:}

Announcer: Bagaimana mengawasi anak ketika libur akhir pekan? Biasanya ketika mereka libur sekolah digunakan untuk bermain dengan teman-temannya bahkan kadang tanpa diketahui orang tua.

Informant: Libur sekolah atau libur akhir pekan memang seharusnya digunakan untuk family time sehingga akan terbangun kedekatan hubungan antara orang tua dan anak. Ketika senin sampai jumat orang tua bekerja dan anak sekolah, seharusnya weekend menjadi waktu bagi keduanya untuk bertemu, berbagi cerita dan bercanda bersama. Kalaupun ketika libur memilih pergi dengan temannya, sebaiknya orang tua mengetahui dengan siapa anaknya pergi dan pergi kemana, kalau bisa juga orang 
tuanya juga punya kontak teman-teman anaknya sehingga bisa menjadi jembatan pengawasan orang tua.

Announcer: Lalu bagaimana agar anak bisa lebih memilih menghabiskan libur akhir pekan bersama orang tua daripada main dengan teman-temannya?

The speech fragments show the ideological factor of language with indicators of language fidelity due to the presence of speech partners. The conversation predominantly uses Indonesian. In addition, several foreign language lingual units, in this case, English, are also used. The conversation between the announcer and the speaker contained two words which had the same meaning, but in different language codes, namely 'weekend' and 'weekend'. The meaning of these two words is 'weekend'. In the context of the conversation, the speech partner, in this case, the source, "teases" the use of the announcer's language by using a foreign lingual unit, namely "weekend". However, in response, the broadcaster did not seem affected by the choice of the source's language as a speech partner. The announcer chooses to stick to Indonesian vocabulary, namely weekends. In this context, the ideological factor of language which is reflected through language loyalty is the determining factor. The announcer may follow the choice of words from the source as a speech partner, but the announcer still uses his own choice of words in Indonesian.

\section{External Factor}

An external factor that has the potential to influence a person's language choice is the presence of a speech partner (the inclusion of other language ideologies). Here's the explanation.

\section{Factors of the Presence of Speech Partners (Inclusion of Other Language Ideologies)}

As explained in the factor of liking (affective component) and language loyalty, the presence of a speech partner brings the ideology of another language that enters the news announcer. The speech uttered by someone is not simple but contains a complex language ideology from the results of one's language processing which is then discouraged through a communication process that will be conveyed to the speech partner. This communication process is a pathway for ideology / other language attitudes into the broadcaster's cognitive component which is then processed into the broadcaster's effective component. After processing it into the affective component, the ideology of other languages will be considered to be continued or returned to the original language by the news announcer who then comes out with a conative component in response. At that time the announcer stood on two knowledge, namely his knowledge and other knowledge (ideology/language attitude) from the speech partner. Here's the explanation.

\section{Contexts :}

Elshinta Semarang Radio announcer interviewed the Ngaliyan Police Headquarters, AKP Wahono regarding the accident that occurred in Silayur derivative, Ngaliyan, Semarang City.

\section{Speech:}

Announcer: Pak Wahono, dampak kecelakaan karambol yang terjadi ini, bagaimana dengan kondisi arus lalu lintas di sekitar lokasi kejadian?

Informant: Baik dilaporkan kondisi arus lalu lintas di sini (turunan Silayur) terpantau padat volume kendaraan yang melintas, sempat terjadi antrian karena memang saat ini jam pulang kerja. Oleh karena itu kami membuka satu lajur dari arah Semarang ke arah Boja Kendal sehingga saat ini diberlakukan sistem 3-1 karena satu lajur paling kiri masih digunakan untuk evakuasi kendaraan yang terlibat kecelakaan. Demikian

Announcer: Pak, bagaimana upaya yang akan dilakukan oleh kepolisian agar dapat mengantisipasi kecelakaan karambol yang sering terjadi di Silayur ini utamanya di jam sibuk ketika volume kendaraan yang melintas padat?

Informant: Baik Mas. Kami sejak bulan Februari lalu bersama dinas perhubungan sudah mengkaji beberapa kebijakan untuk dapat 
diterapkan di turunan Silayur ini mengingat seringnya terjadi kecelakaan karambol di Silayur ini. Berdasarkan catatan kami, faktor dominan penyebab kecelakaan di Silayur adalah karena faktor pengereman. Tonase kendaraan yang sangat berat mengakibatkan kendaraankendaraan berat tersebut mengalami gagal pengereman di turunan. Oleh karena itu, kami sedang mengkaji terkait pembatasan jam operasional bagi kendaraan berat yang melintas di Silayur ini. Akan tetapi ini masih dalam kajian dan belum diputuskan.

The interview fragment has two symptoms of language attitude. Two words were identified in the language attitude symptom, namely carom and volume. The word volume was first uttered by the resource person, which was then followed by the broadcaster. The word volume in the sentence is intended to describe road conditions that are filled with vehicles. However, the word used to describe this condition is the volume of the vehicle. Meanwhile, the meaning of the word volume in the large Indonesian dictionary is the content or size of objects in space, so if the word volume is followed by a vehicle, the phrase will mean the content or size of a vehicle. The meaning does not match the context of the sentence. The word volume is an ordinary word that is often used daily, of course, the sources and announcers have already known its meaning so that the use of the word volume in the sentence should also be adjusted. However, the use of the word volume in a sentence is not appropriate because the sources and announcers are misguided and inaccurate in their usage. The context of the sentence allows the broadcaster to think about the justification for using the correct volume word when the source is uttering it so that he or she does not repeat the same mistakes. However, broadcasters still use it exactly as the sources say. This indicates that the publisher thought it was correct or thought it was normal. This also shows the influence of the source on the attitude of the announcer's language.

Symptoms of other language attitudes are also present in the context of the interview fragment. The language attitude symptom is found in the word 'carom'. The word karambol was uttered three times, twice by the announcer and once by the resource person. Lexically, carom is a game that is similar to billiards but uses your fingers as a flick with a round plate made of plastic instead of a ball. The principle of the carom game is to strike between the plates (balls) to insert into the holes. This parable is used by broadcasters in the use of the word carrom in the context of accidents involving many vehicles. Symptoms of this language attitude include language pride. The announcer tries to get out of the lexical meaning to develop other associative meanings of the word carom. The language development carried out by the announcer seemed to be well received and understood by the speakers, so that the word carrom was also used in the parable of accidents involving several vehicles. This shows that there is influence between broadcasters and sources, they influence each other in terms of language use.

\section{CONCLUSION}

The choice of words (diction) for news announcers Radio Elshinta Semarang and Radio Republik Indonesia (RRI) Pro 1 Semarang is influenced by two factors, namely internal factors, and external factors. Internal factors are found in four indicators, namely mastery of Indonesian language rules (the cognitive component), mastery of other languages (language contact), preferences (affective component), and language ideology (language belief). The ideology of language is a major determinant of language attitudes and language behavior. Meanwhile, one indicator found external factors, namely the presence of speech partners. External factors, the presence of speech partners, will test all internal factors of broadcasters. This is because there is new knowledge/ideology that comes through the process of communication from speech partners to news announcers Radio Elshinta Semarang and Radio Republik Indonesia (RRI) Pro 1 Semarang. In this condition, broadcasters will stand on two knowledge / two ideologies, namely their own knowledge/ideology and the knowledge/ideology of speech partners they 
absorb through the communication process they carry out. Later, the internal factor of the broadcaster will determine the attitude of the actualized language through his language behavior.

\section{REFERENCES}

Adyana, S. and Fathur R. (2016). Akomodasi Bahasa Pada Masyarakat Kota Pekalongan Etnis Jawa-Tionghoa-Arab dalam Ranah Perdagangan. Seloka: Jurnal Pendidikan Bahasa dan Sastra Indonesia, Vol. 5, No 1, Page 88 - 95.

Apriliyani, N., and Fathur R. (2016). Strategi Pilihan Bahasa Pengusaha Industri di Kecamatan Ajibarang Kabupaten Banyumas. Seloka: Jurnal Pendidikan Bahasa dan Sastra, Vol 5, No 2, Page 184191.

Alwi, Hasan, Dardjowidjojo, Soenjona, Lapoliwa, Hans, Moeliono, and Anton M. (2000). Tata Bahasa Baku Bahasa Indonesia: Edisi Ketiga. Jakarta: Balai Pustaka.

Anwar, R. (1984). Pengantar Jurnalistik. Yogyakarta: Pustaka Pelajar.

Azis, E. A. (2013). Budaya Inti, Sikap Bahasa dan Pembangunan Karakter Bangsa: Kasus Penutur Bahasa-Bahasa Daerah Utama di Indonesia. Jurnal masyarakat linguistik Indonesia, Tahun ke-31 No. 2, Page 115 - 139

Azwar, S. (2012). Sikap Manusia: Teori dan Pengukurannya. Yogyakarta: Liberty.

Eliya, I., and Ida Z. (2018). Pola Komunikasi Politik Ganjar Pranowo dalam Perspektif Sosiolinguistik di Media Sosial Instagram. Seloka: Jurnal Pendidikan Bahasa Dan Sastra Indonesia, Vol 6, No 1, Page 286-296.
Koentjaraningrat. (1990). Kebudayaan Mentalitas dan Pembangunan. Jakarta: Gramedia Pustaka Utama.

Marsudi and Siti Z. (2015). Kesetiaan Berbahasa Indonesia Dipertanyakan di Era Globalisasi. Jurnal Sosial Humaniora, Vol 8 No.1, Page 95 - 104.

Ranasuriya D. (2015). Effects of Radio and Television Media on Language. Mass Communication \& Journalism. University of Vocational Technology, Srilanka, Vol.5, No.6, Page 265.

Santoso, A. (2009). Bahasa Perempuan. Jakarta: Bumi Aksara.

Savitri, E.D. and Siti Z. (2016). "Sikap Pilihan Bahasa Pelaku Ekonomi Berdasarkan Tinjauan Undang-Undang dan Peraturan Pemerintah". Jurnal Sosial Humaniora, Vol 9, No 2, Page 156 - 169.

Sugiyono. (2008). Metode Penelitian Kuantitatif Kualitatif dan $R \& D$. Bandung : Alfabeta.

Suwito. (1996). Pengantar Awal Sosiolinguistik. Teori dan Problema. Surakarta: Henary Offset Solo.

Tobing, S. (1991). Development Journalism in Indonesia: Content Analysis of Government Television News. Disertasi. Ohio University.

Wahyu, Tri R.N. (2006). Bahasa Indonesia. Jakarta : Universitas Gunadarma.

Wardhani, P., Mimi M., and Fathur R. (2018). Wujud Pilihan Bahasa dalam Ranah Keluarga Pada Masyarakat Perumahan di Kota Purbalingga. Kredo: Jurnal Ilmiah Bahasa dan Sastra, Vol 1 No 2, Page 91-105.

Widianto, E. and Ida Z. (2016). Pilihan Bahasa dalam Interaksi Pembelajaran Bahasa Indonesia bagi Penutur Asing. Seloka: Jurnal Pendidikan Bahasa dan Sastra, Vol 5, No 2, Page 124- 135

Zulaeha, I. (2016). Teori Dialektologi, Dialek Sosial dan Regional. Semarang: UNNES Press. 